\title{
Bilateral phlegmasia cerulea dolens in an occluded inferior vena cava filter
}

\author{
Jessamy Diana Bagenal, David Nasralla
}

Department of General Surgery, Bristol Royal Infirmary, Bristol, UK

\section{Correspondence to} Jessamy Diana Bagenal, jessamy.bagenal@gmail.com

\section{DESCRIPTION}

A 70-year-old lady presented with severely painful, swollen and discoloured legs of $24 \mathrm{~h}$ onset. She had deteriorated quite rapidly over the last $12 \mathrm{~h}$ gradually becoming less responsive. Prior to this she had been well and independent.

Her medical history included atrial fibrillation, for which she took aspirin, and a deep vein thrombosis 15 years ago, following which she was found to have a caecal carcinoma and required the placement of an inferior vena cava (IVC) filter in order to have it resected safely and successfully in 1999 .

On examination she was found to be in discomfort. She had an irregular pulse at 100 and a blood pressure of 100/60, her respiratory rate was $24 / \mathrm{min}$. An arterial blood gas revealed a $\mathrm{pH}$ of 7.35 , and base excess of -10.3 . Her back was

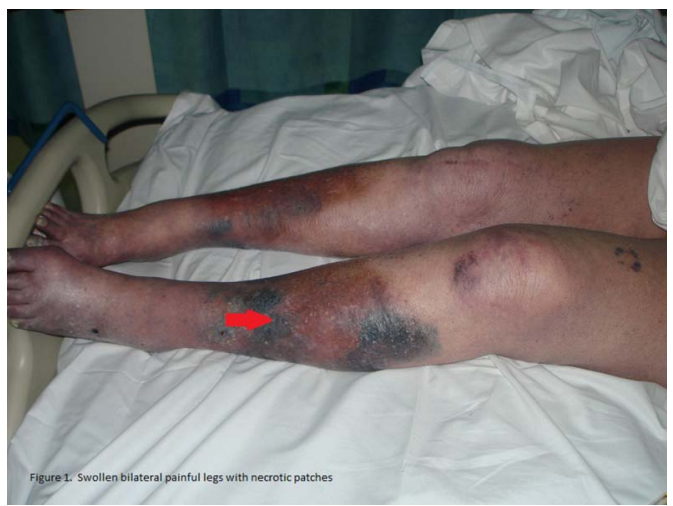

Figure 1 Bilaterally painful, swollen legs with necrotic

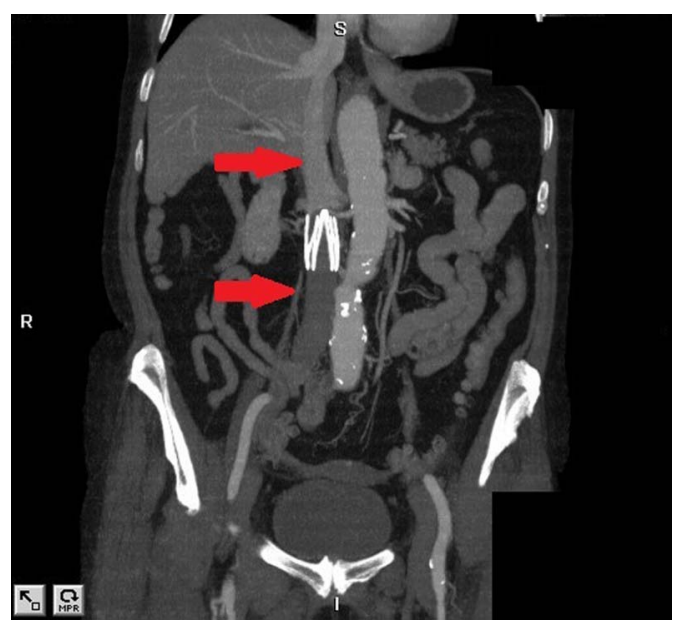

Figure 2 CT angiogram aorta: revealing no contrast below the IVC filter. tender over the lumbar paravertebral muscles and both loins. On examination her both legs were found to be grossly swollen and discoloured with patches of necrotic skin (figure 1). Peripheral pulses were present bilaterally and her feet were wellperfused with a minimal alteration of sensation.

Basic resuscitative measures were initiated and a CT angiogram scan of her aorta promptly requested. The CT scan revealed an absence of contrast below the IVC filter but its presence above; the acute onset suggested complete occlusion of the IVC filter (figure 2). A diagnosis of phlegmasia cerulea dolens was made secondary to occluded IVC filter. Unfortunately she was not fit for theatre and palliative measures were undertaken, she died $6 \mathrm{~h}$ later.

\section{Learning points}

- Phlegmasia cerulea dolens is a rare consequence of massive proximal (eg, iliofemoral) venous thrombosis of the lower extremities associated with a high degree of morbidity that can present in similar ways to the acutely ischaemic limb with lower pain, swelling and discolouration. ${ }^{1}$ Its diagnosis must be established quickly in order to improve survival.

- Inferior vena cava (IVC) filter occlusion owing to thrombosis increases over time. A radiological surveillance study identified IVC occlusion rates of $22 \%$ at 5 years and $33 \%$ at 9 years of follow-up (Crochet et al, 1999). Its consideration as a diagnosis must be remembered when dealing with patients with permanent IVC filters. ${ }^{2}$

- There are two forms of IVC filter; a tethered filtration device or a retrievable filter. However, there is no strong evidence that one is better than the other. Retrievable filters should be used, if available, for patients with a short-term contraindication to anticoagulant therapy (eg, approximately 2 weeks). When used retrievable filters must be promptly removed in order to minimise the long-term complications of IVC filters. ${ }^{2}$

\section{Competing interests None.}

Patient consent Obtained.

Provenance and peer review Not commissioned; externally peer reviewed. 


\section{REFERENCES}

1 Vysetti S, Shinde S, Chaudhry S, et al. Phlegmasia cerulea dolens-a rare, life-threatening condition. ScientificWorldJournal 2009;9:1105-6.
2 British Committee for Standards in Haematology, Baglin TP, Brush J, et al. Guidelines on use of vena cava filters. Br J Haematol 2006;134:590-5.

Copyright 2013 BMJ Publishing Group. All rights reserved. For permission to reuse any of this content visit http://group.bmj.com/group/rights-licensing/permissions.

BMJ Case Report Fellows may re-use this article for personal use and teaching without any further permission.

Become a Fellow of BMJ Case Reports today and you can:

- Submit as many cases as you like

- Enjoy fast sympathetic peer review and rapid publication of accepted articles

- Access all the published articles

- Re-use any of the published material for personal use and teaching without further permission

For information on Institutional Fellowships contact consortiasales@bmjgroup.com

Visit casereports.bmj.com for more articles like this and to become a Fellow 